\title{
Prophylactic effect of tamoxifen against induction of mammary carcinoma
}

\author{
Gabri MS ${ }^{(1)}$, Osman AM ${ }^{(2)}$, El-Sayed $M^{(2)}$ and Negm Somaia.A ${ }^{(2)}$
}

(1) Department of Zoology, faculty of science, Helwan University

(2) Pharmacology and Experimental therapeutic Unit, Cancer biology Dep., National Cancer

Institute, Cairo University

\begin{abstract}
Tamoxifen (TAM) is a potent anticancer agent known to interrupt the enhanced estrogen activity of malignant mammary gland cells, The mechanism of tamoxifen's anti-tumor activity is primarily due to its anti estrogen action. Female Swiss albino mice were used in the present study and divided into:- normal control group, two Ehrlich ascites carcinoma (EAC) control groups [treated interaperitonealy(IP) and subcutaneously (Sc)], tamoxifen treated only group, tamoxifen pre treated then EAC (S.C) injected group and tamoxifen pre treated then EAC (I.P) injected group.

The present results showed a significant decrease in tumor volume and a significant increase in the survival time in the pre-treated group compared to untreated group. There was a pathological change in the uterine tissues of the tamoxifen treated mice in the form of squamous metaplasia and dysplasia of glandular epithelial. The kidney tissues showed a minimal pathological change in the form of a focal renal lesion in the renal tubular epithelium. in conclusion the present study showed that tamoxifen has a prophylactic effect against experimental mammary carcinoma. And exerts some side effects on the histopathological structure of the uterine and kidney tissues. Key words: Tamoxifen, Mammary carcinoma, experimental, prophylactic, side effect.
\end{abstract}

\section{Introduction:}

Breast cancer is becoming an increasingly important disease in all parts of the world, where it is one of the major causes of mortality and show steady dramatic increase (1). In Egypt, data reported by Mokhtar, (2) indicated that breast cancer ranked as number one $(27.3$ $\%$ ) among females. Approximately $30 \%$ of women diagnosed with breast cancer go on to develop metastatic disease which is ultimately fatal (3). Over the last 40 years substantial progress has been made in the diagnosis and treatment of breast cancer. Further more dramatic effort have been made to detect risk factors that will help of identify those women likely to develop breast cancer and have generated efforts to prevent it.

Since estrogen can promote the development of cancer in the breast and uterus, it seems logical to postulate that

substances that block the action of estrogen might be helpful in preventing or treating these two types of cancer. This rationale has led scientists to work on the development of "anti-estrogen" drugs that can block the action of estrogens and thereby interfere with, or even prevent, the proliferation of breast and uterine cancer cells.

Tamoxifen is a potent anticancer agent known to interrupt the enhanced estrogen activity of malignant mammary gland cells, and exerts this anti-estrogenic effect by binding to the estrogen receptors of breast cells, thereby preventing estrogen molecules from binding to these receptors. But unlike the normal situation, when estrogen binds to its receptor, the binding of tamoxifen to the receptor does not cause the receptor molecule to acquire the changed shape that allows it to bind to coactivators, 
as a result, the genes that stimulate cell proliferation cannot be activated (4)

\section{Material And Methods}

Female Swiss albino mice weighing 25-30 g. were used in the present study. The animals were housed in the experimental animal house National Cancer Institute, Cairo University. and maintained on a standard pellet diet and water $a d$ libitum. The diet consisted of not less than $20 \%$ protein, $5 \%$ fibers, $3.5 \%$ fats and $6.5 \%$ ash and supplied with vitamins mixture and carbohydrates.

Drugs:

Tamoxifen powder (tamoxifen citrate), was prepared for injection by adding $200 \mu \mathrm{l}$ of tween 20 to the $40 \mathrm{mg}$ TAM powder in clean mortar and grinding very well. After that, $20 \mathrm{ml}$ of normal saline was added and mixed very well till a suspension solution was formed. The drug was diluted to a final concentration equal to $20 \mathrm{mg} / \mathrm{kg}$ (5), (6). Tamoxifen was prepared fresh just before oral administration.

\section{Ehrlich Ascite Carcinoma (EAC) cell line:}

The tumor cell line was maintained in female Swiss albino mice at the national cancer institute by serial i.p. passages in female Swiss albino mice at 7-10 days interval. The EAC cells were prepared as follows:-

a- Ascites fluid was withdrawn under aseptic conditions (using ultra violet laminar air flow system) from tumorbearing mice by needle aspiration from the peritoneal cavity, 7-10 days after EAC cells implantation.

b- The cells in the ascetic fluid were tested for viability and contamination by using trypan blue dye exclusion technique in which equal volume of trypan blue dye $(0.1 \%)$ and the samples were mixed together on a slide (haemocytometer) and the cells were examined microscopically. Trypan blue stain the dead cells only.
The cells were counted on Haemocytometer and diluted to a final concentration equal to $2 \times 10^{6}$ cells.

\section{Methods:-}

1- Effect of TAM pre-treatment on survival time of EAC-bearing mice.

A total 80 of female mice were divided at random into 4 groups of 20 animals each and treated as following:

Group I (control): Animals were injected orally with normal saline 3 times/week for 3 weeks and then injected I.P with $2 \times 10^{6}$ EAC-cells.

Group II (treated): Animals were injected orally with TAM $(20 \mathrm{mg} / \mathrm{kg}) 3$ times/week for 3 weeks and then injected I.P with $2 \times 10^{6}$ EAC-cells.

Group III (control): Animals were injected orally with normal saline 3 times/week for 6 weeks and then injected I.P with $2 \times 10^{6} \mathrm{EAC}$-cells.

Group IV (treated): Animals were injected orally with TAM $(20 \mathrm{mg} / \mathrm{kg}) \quad 3$ times/week for 6 weeks and then injected I.P with $2 \times 10^{6}$ EAC-cells.

At the end of each treatment period, survival time of each mouse was recorded and the mean survival time of each group was then calculated.

\section{2- Effect of TAM pretreatment on the growth of Solid Ehrlich Carcinoma (SEC). \\ A total of 80 female mice were divided at} random into 4 groups of 20 animals each and treated as following:

Group I (control) : Animals were injected orally with normal saline 3 times/week for 3 weeks and then injected S.C in the right lower limb with $2 \times 10^{6}$ EAC-cells.

Group II (treated) : Animals were injected orally with TAM $(20 \mathrm{mg} / \mathrm{kg}) 3$ times/week for 3 weeks and then injected S.C in the right lower limb with $2 \times 10^{6}$ EAC-cells.

Group III (control) : Animals were injected orally with normal saline 3 times/week for 6 weeks and then injected S.C in the right lower limb with $2 \times 10^{6}$ EACcells. 
Group IV (treated) : Animals were injected orally with TAM $(20 \mathrm{mg} / \mathrm{kg}) 3$ times/week for 6 weeks and then injected S.C in the right lower limb with $2 \times 10^{6}$ EAC-cells.

The change in tumor volume as response to treatment was measured by Vernir caliper every $48 \mathrm{hrs}$ using the following formula:

Tumor volume $(\mathrm{mm})^{3}=4(\mathrm{~A} / 2)^{2}(\mathrm{~B} / 2)^{2}=$ $0.52 \mathrm{AB}$

Where: $\mathrm{A}$ is the major tumor axis and $\mathrm{B}$ is the minor axis

\section{3- Effect of TAM on organ toxicity:}

The toxic effects of long-term administration (6weeks) of TAM were determined by detecting histopathological changes in uterus, kidney, spleen and liver tissues.

A total of 40 female-mice were divided random into tow groups, 20 animals each. The first group was injected orally with normal saline 3 times/week for 6 weeks and served as control while number of the second group received, orally, the calculated dose of TAM $(20 \mathrm{mg} / \mathrm{kg}) 3$ times /week, for 6 weeks.

The animals were sacrified and the uterus, kidney, liver and spleen were dissected and were immediately fixed in $10 \%$ formaldehyde solution, dehydrated in ascending grades of alcohol, cleared in terpineol and embedded in paraffin. Sections 5-6 $\mu \mathrm{m}$ thick were cut, mounted and stained with hematoxylin and eosin. The stained sections were examined microscopically.

\section{-Statistical analysis}

Data were analyzed using the Statistical Package for the Social Sciences (SPSS, version 7.5). All data were expressed as mean value \pm standard error. Mean values of the different variables were compared using the student-t test. Analysis of variance (ANOVA) was used to compare more than two groups. P-value less than 0.05 was considered significant.

\section{Results}

\section{A- Survival time}

The effect of TAM pre-treatment on mean survival time of mice- bearing EAC are shown in table (1) and graphically represented in fig (1).
Pretreatment with TAM for 3 weeks resulted in significant increase $45 \%$ in mean survival time of mice-bearing EAC, where as 6 weeks pretreatment resulted in highly significant increase $75 \%$ These results indicate significant correlation between the duration of TAM pretreatment and mean survival time.

\section{B- Tumor volume}

Table (2) and figure (2) show the effects of TAM pretreatment on the growth of solid EAC in mice.

The tumor volume of the control group showed progressive increase, whereas TAM pretreatment for 3 weeks resulted in significant decrease in the tumor volume.

Increasing the duration of TAM pretreatment for 6 weeks resulted in significant decrease in tumor volume as compared to either control or 3 weeks TAM pretreated groups.

\section{C- Histopathological examination:}

The histopathological examination of the uterus and kidney tissues of TAMtreated mice revealed an obvious variety of alterations (figs. 3-6). Such alterations were in the form of squamous metaplasia and dysplasia of glandular epithelial cells where the cells are large in size, with vesicular and prominent nuclei with the appearance kerato hyaline granules (figs. $3 \& 4$ ).

There was a minimal pathological change in the kidney tissue in the form of a focal renal lesion in the renal tubular epithelium where the cells appeared with higher nuclear cytoplasmic ratio, hyperchromatic nuclei and dense eosinophilic cytoplasm (figs.5\&6).

The histopathological examination of the liver tissue in treated mice showed that there is no change where the hepatocytes showed preserved lobular pattern and arranged in trabeculae separated by sinusoids (figs $7 \& 8$ ).

The examination of the spleen tissue showed that there is no histopathological change, where the white pulp shows a small mature lymphocytes and the red pulp showed that sinuses are distended by histiocytes (figs.9\&10). 
Table (1) : Effect TAM pretreatment on the mean survival time of mice-bearing Ehrlich Ascites Carcinoma.

\begin{tabular}{|l|l|}
\hline Groups and duration of treatment & Mean survival time ( days) \\
\hline \multicolumn{1}{|c|}{ Control } & $14.8 \pm 0.32$ \\
TAM-3 weeks & $21.4 \pm 1.13^{* *}$ \\
TAM-6 weeks & $25.8 \pm 1.27^{* *}$ \\
\hline
\end{tabular}

- Data are presented as mean \pm SEM $(n=20)$

**: indicate significant change from control at $\mathrm{P}<(0.001)$.

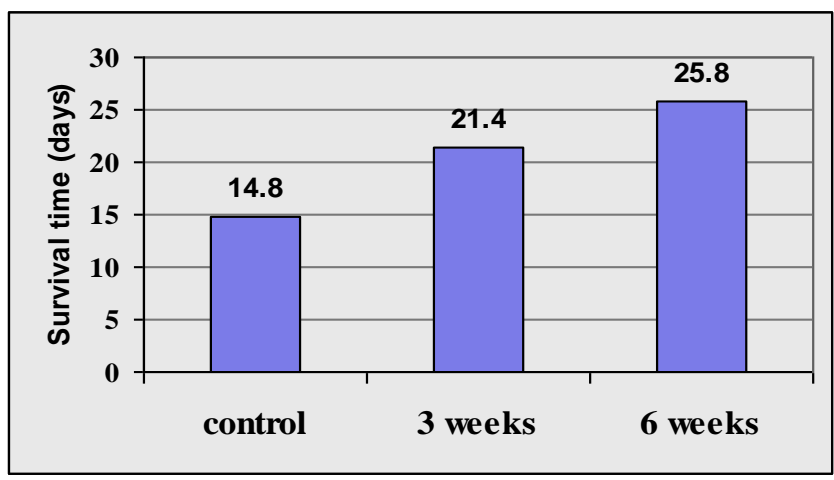

Fig. (1): Effect TAM pretreatment on the mean survival time of mice-bearing Ehrlich Ascites Carcinoma.

- Data are presented as mean \pm SEM $(n=20)$

- **: indicate significant change from control at $\mathrm{P}<(0.001)$.

Table (2): Effect of TAM pretreatment on the growth of Solid Ehrlich Carcinoma

\begin{tabular}{|c|c|c|c|c|c|c|c|c|c|}
\hline $\begin{array}{l}\text { Groups \& } \\
\text { duration of } \\
\text { treatment }\end{array}$ & 6 & 8 & 10 & 13 & 15 & 17 & 20 & 22 & 26 \\
\hline Control & $278 \pm 11$ & $518 \pm 33$ & $957 \pm 114$ & $\begin{array}{c}1311 \pm \\
117\end{array}$ & $\begin{array}{c}1472 \pm \\
263\end{array}$ & $\begin{array}{c}1689 \pm \\
201\end{array}$ & $\begin{array}{c}1779 \pm \\
224\end{array}$ & $\begin{array}{c}1809 \pm \\
207\end{array}$ & $\begin{array}{c}2149 \pm \\
221\end{array}$ \\
\hline $\begin{array}{c}\text { TAM } \\
3 \text { weeks }\end{array}$ & $\begin{array}{l}174 \pm \\
19 * * *\end{array}$ & $380 \pm 53^{*}$ & $\begin{array}{l}506 \pm \\
74 * *\end{array}$ & $\begin{array}{l}814 \pm \\
71 * * *\end{array}$ & $\begin{array}{c}1029 \pm \\
97 *\end{array}$ & $\begin{array}{c}1102 \pm \\
123^{*}\end{array}$ & $\begin{array}{c}1177 \pm \\
198^{*}\end{array}$ & $\begin{array}{c}1328 \pm \\
227\end{array}$ & $\begin{array}{c}1474 \pm \\
162 *\end{array}$ \\
\hline $\begin{array}{l}\text { TAM } \\
6 \text { weeks }\end{array}$ & $\begin{array}{c}0 \\
\text { Not } \\
\text { detected }\end{array}$ & $\begin{array}{c}240 \pm \\
10.5 * * * \\
\$ \$\end{array}$ & $\begin{array}{c}295.7 \pm \\
17.2 * * * \\
\$ \$\end{array}$ & $\begin{array}{c}342 \pm \\
25.2^{* * * *} \\
\$ \$ \$\end{array}$ & $\begin{array}{c}446.5 \pm \\
37.2^{* * *} \\
\$ \$ \$\end{array}$ & $\begin{array}{c}518 \pm \\
54.2 * * * \\
\$ \$ \$\end{array}$ & $\begin{array}{c}557 \pm \\
74^{* * * *} \\
\$ \$\end{array}$ & $\begin{array}{c}582 \pm \\
62 * * * \\
\$ \$\end{array}$ & $\begin{array}{c}617 \pm \\
58 * * * \\
\$ \$ \$\end{array}$ \\
\hline
\end{tabular}

Data are expressed as mean \pm SEM $(n=20)$.

* Significant from control at $p<0.05$

** Significant from control at $p<0.01$

*** Significant from control at $\mathrm{p}<0.001$

$\$$ Significant from 3 weeks at $p<0.05$

$\$ \$$ Significant from 3 weeks at $p<0.01$

$\$ \$ \$$ Significant from 3 weeks at $p<0.001$ 


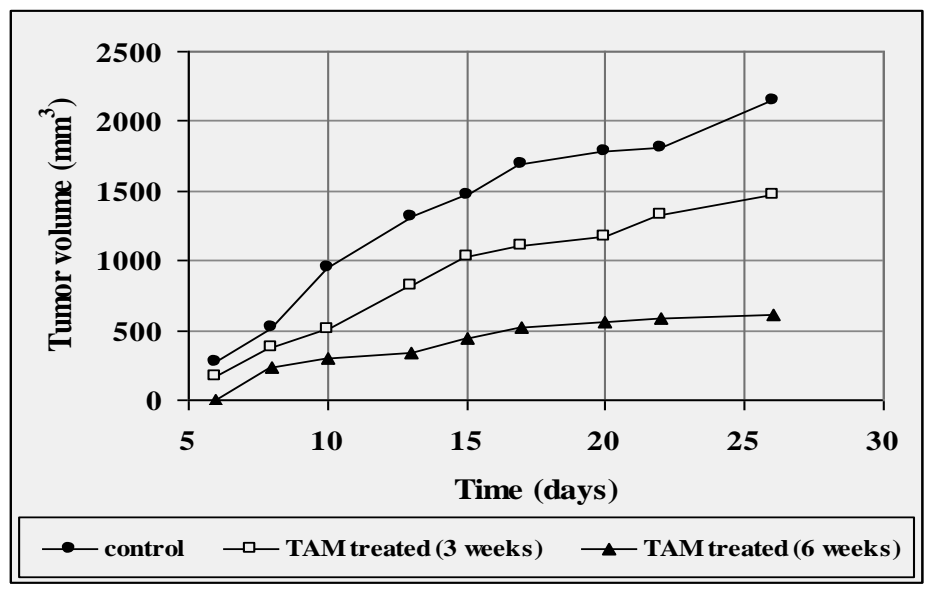

Fig. (2): Effect of TAM pretreatment on the growth of Solid Ehrlich Carcinoma.

- Data are presented as mean $\pm \operatorname{SEM}(n=20)$

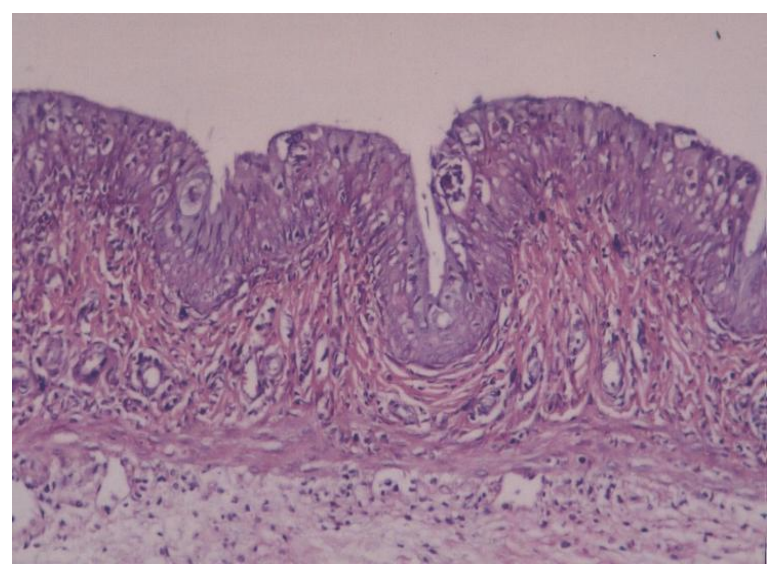

Fig (3): Photomicrograph of a T.s. of the uterus of control mouse showing the glandular epithelial cells of endometrium. Lumen of the uterus is shown at the top (H\&E $\times$ 100)

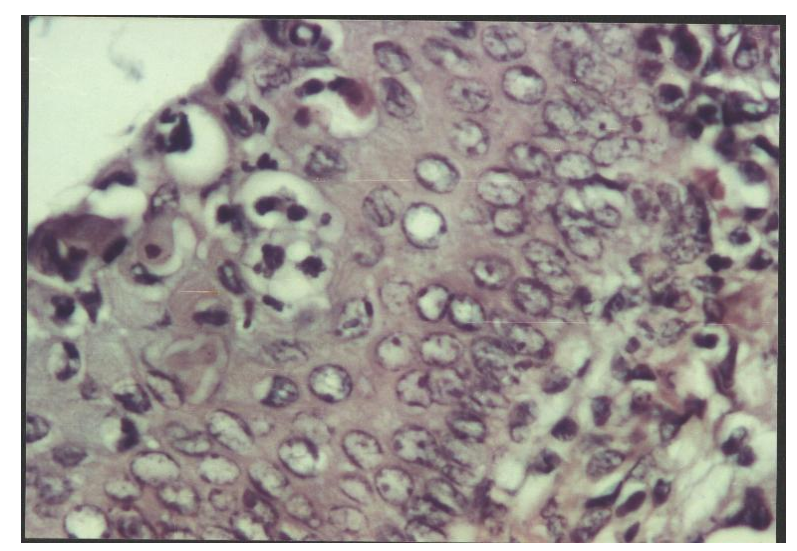

Fig (4): Photomicrograph of a T.s. of the uterus of TAM-treated mouse showing dysplastic squamous cells, and the lining endometrium (following drug application) are large in size, with vesicular nuclei and prominent nuclei. Kerato hyaline granules are abundant in upper layers. $(\mathrm{H} \& \mathrm{E} \times \mathbf{4 0 0})$ 


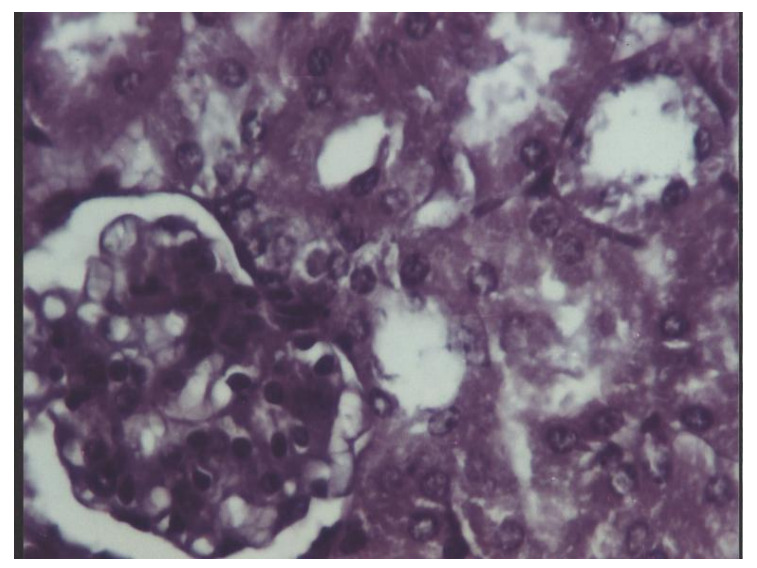

Fig (5): Higher magnification reveals renal cortexof control mouse showing glomerulus and cortical tubule. $(\mathrm{H} \& \mathrm{E} \times \mathbf{4 0 0})$

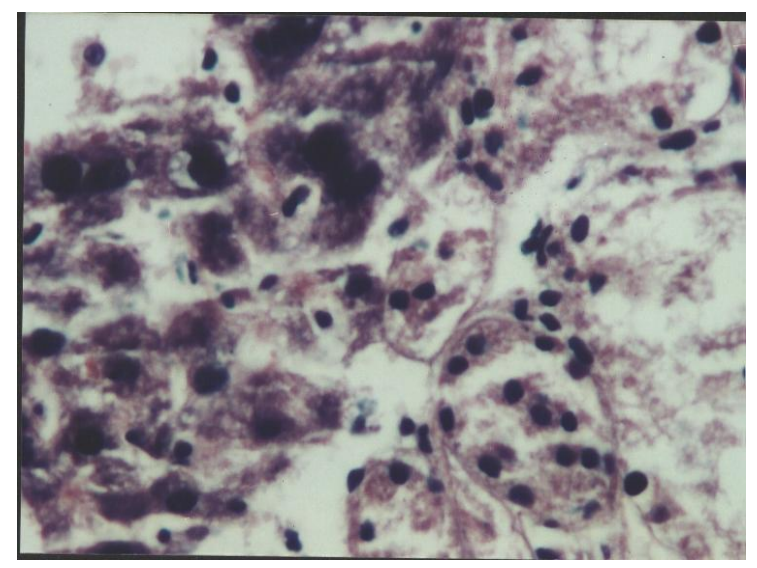

Fig (6) Higher magnification of the renal cortex of TAM-treated mouse showing renal tubular epithelial cells with higher nuclear cytoplasmic ratio, hyper chromatic nuclei and dense esinophilic cytoplasm. (H \&E $\times$ 400)

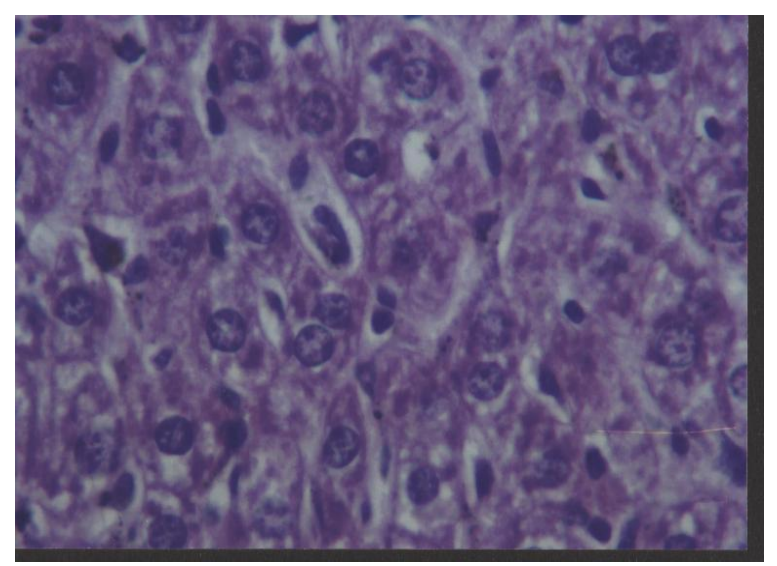

Fig (7): Photomicrograph of a section of the liver of control mouse showing hepatocytes arranged in trabeculae separated by sinusoids $(H \& E \times 400)$ 


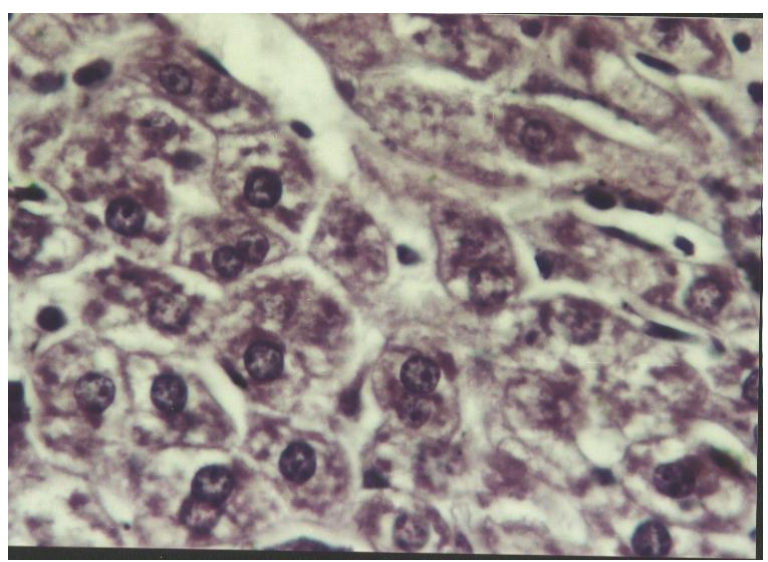

Fig (8) Photomicrograph of section from the liver of TAM- treated mice, showing no pathological changes $(\mathrm{H} \& \mathrm{E} \times 400)$

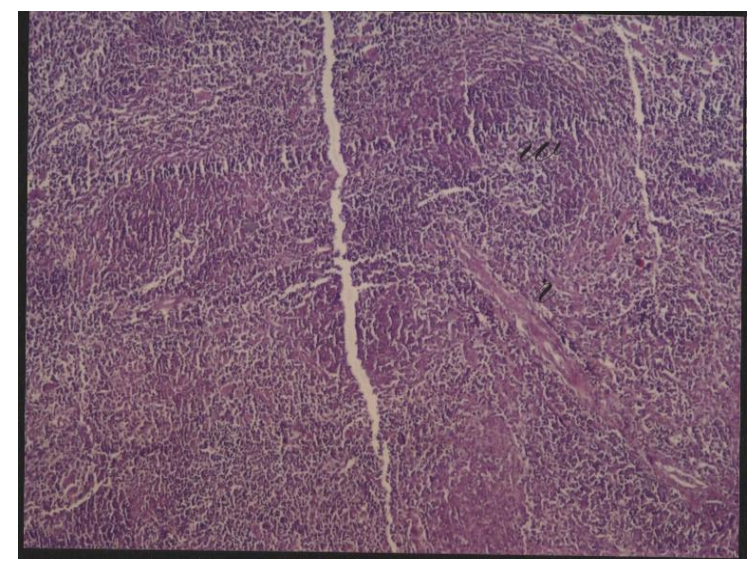

Fig (9): Photomicrograph of a T.s. of the spleen of control mouse showing bluish areas representing lymphoid tissues of the white pulp and pinkish areas of red pulp $(\mathbf{H} \& \mathbf{E} \times 100)$.

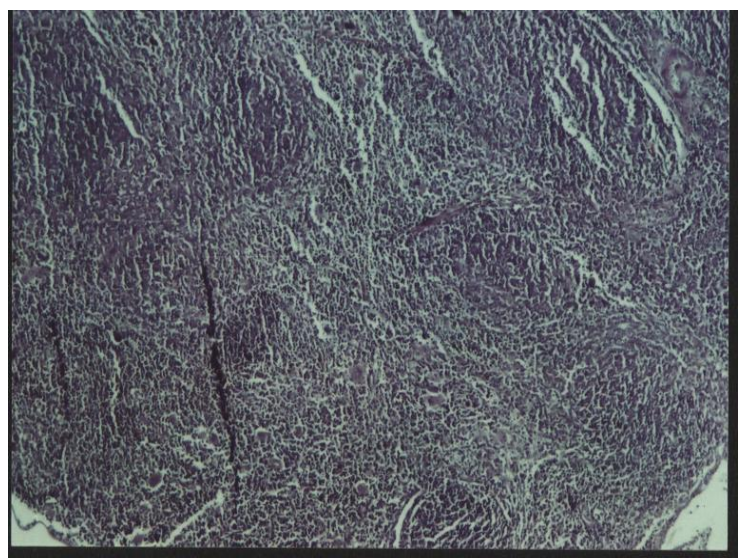

Fig (10): Photomicrograph of a T.s. of the spleen of mice treated with tamoxifen for 6 weeks revealing no pathological changes $(\mathrm{H} \& \mathrm{E} \times 100)$ 


\section{Discussion}

Tamoxifen was recently approved by the Food and Drug Administration (FDA) for the treatment of breast cancer (7). It is a synthetic antiestrogen that has been used since the $1970^{\mathrm{s}}$ to treat advanced and early stage breast cancer (8). The drug is classified as a selective estrogen receptor modulator (SERM) because it behaves like an estrogen agonist in some tissues and an antagonist in others (9). The mechanism of tamoxifen's antitumor activity is primarily due to its anti estrogen action (10). Estrogen, when acting as a harmful hormone, has to promote cancer of the breast and uterine lining. Tamoxifen is a synthetic estrogen-like hormone that binds to the estrogen receptors and act as a competitor of natural estrogen to inhibit the growth of malignant mammary tumors (8).

The administration of tamoxifen has significantly improved free survival and overall survival in women with breast cancer, this is indicated in many trials. In one trial, two thousand eight-hundred and ninety-two patients were randomized to receive tamoxifen (11), the results indicated a significant prolongation of disease-free survival rate in favor of the group received tamoxifen treatment.

This beneficial effect of tamoxifen was also noted in other randomized trials and has been confirmed by a worldwide meta-analysis of tamoxifen trials (12).

In the present study, we have tested the possible prophylactic effect of oral administration of tamoxifen $(20 \mathrm{mg} / \mathrm{kg})$ against induction of mammary carcinoma in female mice. Using subcutaneous and intraperitoneal injection of Ehrlich Ascites Carcinoma (EAC) cell line. the results showed a significant reduction in tumor volume in the TAM pre-treated groups, and a significant increase in the mean survival time of EAC-bearing animals. Previous studies have been done to detect the effect of tamoxifen against experimental mammary carcinoma and other types of cancer. In one study to detect the therapeutic benefit of TAM on the growth and invasive properties of human mammary cancer cells, female nude mice inoculated sub-cutaneously with human MCF-7 mammary adeno-carcinoma cell line. The present results are in good agreement with pervious studies which have concluded that the oral treatment of mice with TAM resulted in statistically significant inhibition of tumor growth and the median survival time of tumor-bearing mice was increased than other groups (13).

In a study done by perry et al. (14) to evaluate the effects of tamoxifen on growth and apoptosis of estrogen-dependant and independent human breast cancer cells, they reported that TAM exerts anti-proliferative and cytotoxic effects in breast and nonbreast cells.

In the present study the tumor volume of the TAM pre-treated groups was significantly reduced in comparison to control group which showed progressive increase in the growth of Solid Ehrlich Carcinoma.

In a study done by EBCT group, (15) they reported that adjuvant tamoxifen therapy reduce the number of recurrent and prolong survival in woman has primary tumor with positive estrogen receptor .

Cuzick et al., (16) out lined the theoretical bases for using tamoxifen on prevention trail. He argued this to a logical extension of breast screening and that because of the evidence of the efficacy of tamoxifen, in the established disease without undue side effects. The agent could block the effect of more biologically available estrogen in woman as at risk, (17), (18).

The histopathological result of the present study revealed that tamoxifen induce some side effects, in the uterine tissue in the form of squamous metaplasia and dysplasia of glandular epithelial cells, where the cells are large in size, with vesicular. and prominent nuclei with the appearance of kerato hyaline granules following application of 6 weeks tamoxifen treatment.

Scientists noted that tamoxifen persists for some days in the uterus. In rats, tamoxifen metabolite was found to influence the uterus to be more receptive to 
estrogen. The more estrogen, the greater the chance of unnatural cell-division leading to cancer (19).

Uterine growths such as polyps, tumors, endometrial thickenings and cancers occur in a significant number of women taking tamoxifen. One study detected abnormal endometrial cells in subjects the day after the first tablet was taken (20). Pre-cancerous uterine and endometrial changes were seen in 10 percent of the women taking tamoxifen in a recent study. The higher the dose of tamoxifen and the longer it is taken, the greater the risk of changes. Women taking the standard dose of $20 \mathrm{mg}$. for two years run a risk of uterine cancer that is 2 to 3 times greater than normal. After five years, the risk is 6 to 8 times greater (21).

In February 1996 a review by the International Agency for Research on Cancer, concluded that "there is sufficient evidence to regard tamoxifen as a human carcinogen that increases a woman's risk of developing cancer of the endometrium, the inner lining of the uterus" (22).

The histopathological examination of the kidney tissues showed that there was a minimal pathological change in the form of a focal renal lesion in the renal tubular epithelium where the cells appeared with higher nuclear cytoplasmic ratio, hyperchromatic nuclei and dense eosinophilic cytoplasm.

On the other hand no histpathological changes were detected in the liver and spleen tissues of 6 weeks tamoxifen treated animals, where the hepatocytes showed preserved lobular pattern and arranged in trabeculae separated by sinusoids. In the spleen tissues, the white pulp showed a small mature lymphocytes and the red pulp showed that sinuses are distended by histiocytes . Many other studies indicated abnormality in the liver of rats (using intra peritoneal injection) with different doses of tamoxifen (23), (24).

According to the present data, tamoxifen did not induce any change in the liver tissues. This may be due to: 1- the animals strain where we used mice not rat. 2- The mode of administration where we used oral administration not I.P. injection.
3- The time of exposure to tamoxifen was less than the time of exposure in the other studies.

\section{References:}

1. Negri E., L.a., Vecchia C., Franceschi C. and Levi F. Pattern of mortality from major cancers in Europe. Cancer Epidemiol. Biomarkers Prev.3: 531-37, 1994.

2. Mokhtar N. Cancer pathology registry 19851989, National cancer institute Cairo university, 1991.

3.El-Bolkainy $M$. N. topographical pathology of cancer: $1^{\text {st; }}$ NCI Cairo University P.87, 1998.

4. Dhingra K. ivest. New Drugs, 17, 285, 1999.

5. Suzme R, Gurdol F, Deniz G, Ozden T. Response in DNA ploidy of hepatocytes to tamoxifen and/or melatonin in vivo. Res Commun Mol Pathol Pharmacol. 109(5-6): 275-86 2001.

6. Sargent L.M., Dragan Y.P., Bahnub N., Wiley J.E., Sattler C.A., Schroeder P., Sattler G.L., Jordan V.C., Pitot H.C. Tamoxifen induces hepatic aneuploidy and mitotic spindle disruption after a single in vivo administration to female Sprague-Dawley rats. Cancer Res.Jul, 1; 54(13): 3357-60, 1994.

7. Majumdar S. K., Valderllon J. A. and Brown $K$. $A$. In vitro investigations on the toxicity and cell death induced by tamoxifen on two non-breast cancer cell types. J Biomed Biotechnol. 1(3): 99-107, 2001.

8. Sterns V. and Gelmann E.P. Does tamoxifen case cancer in human. J Clin Oncol. 16, 779-792, 1998.

9-Jordan V.C. Desinger estrogens. Scien Amer 279, 60-67, 1998.

10- Bryant H.U. and Dere W.H. Selective estrogen receptor modulators: an alternative to hormone replacement therapy. Proc Soc Exp Biol Med 217, 45-52, 1998.

11- Fisher B., Costantino J.P., Wicherhan D.L. Tamoxifen for prevention a breast cancer: Report of the National Surgical Adjuvant Breast and Bowel Project. P-1Study. J. Ntil Cancer Inst 90: 1371-1388, 1998.

12- Stewart H.J. Adjuvant tamoxifen duration in a randomized trial. The breast 4(3): 256 (abstract 102) 1995.

13- Marc E., Bracke, Herman T., Depypere, Tom Boterberg, Veerle L., Van Marck, Krist'l M., Vennekens, Eric Vanluchene, Margareta Nuytinck, Rudolphe Serreyn, Marc M., Mareel. Influence of Tangeretin Tamoxifen's Therapeutic Benefit in 
Mammary Cancer. J. Natl. Cancer Inst (91) 4:354-359, 1999.

14- Perry R.R., Kang Y., and Greaves B. Effects of tamoxifen on growth and apoptosis of estrogen-dependant and independent human breast cancer cells. Ann Surg Oncol 2, 238-245, 1995.

15- Group EBCT. Tamoxifen for early breast cancer: on over view of the randomized trails. Lancet 351:1451-1467, 1998.

16- Cuzick J., Wang D.Y., Bulbrook R.D. The prevention of breast cancer. Lancet; 1:8386, 1986.

17- Cuzick J., Boum M. Tamoxifen and contra lateral breast cancer (later) - Lancet; ii 282, 1995.

18- Fornander T., Ceder Mork B., Mattson A. et al. Adjuvant tamoxifen in early breast cancer. Occurrence of new primary cancer. Lancet ii1070-1073, 1989.

19- Sellman Sherrill. Tamoxifen a major medical mistake? Nexus Magazine, volume 5, \#4(June - July) 1998.
20- Early Breast Cancer Trials Collaborative Group, "Systemic treatment of early breast cancer by hormonal, cytotoxic, or immune therapy." The Lancet (339), page 1-15, 7185, 1992.

21- "Studies spark tamoxifen controversy", Science News, February 26, page 133, 1994.

22- Nesmith Jeff. "Breast Cancer Drug Increases Risk:, The Atlanta Journal / The Atlanta Constitution, February 22, 1996.

23- Suzme R, Gurdol F, Deniz G, Ozden T. Response in DNA ploidy of hepatocytes to tamoxifen and/or melatonin in vivo. Res Commun Mol Pathol Pharmacol. 109(5-6): 275-86 2001.

24- Dragan Y.P., Shimel R.J., Bahnub N., Sattler G., Vaughan J.R., Jordan V.C., Pitot $H C$. Effect of chronic administration of mestranol, tamoxifen, and toremifene on hepatic ploidy in rats. Toxicol Sci. Jun; 43(2): 129-38 1998. 


\section{التاثيز الوقائي لعقار التاموكسفين ضد حدوث سرطان الثابدي}

*محمد الجابرى ، **عبد المنعم محمود عثمان، **محمد محمد السيد، **سمية

عبد المنعم نجم

*قسم علم الحيو ان ـ كلية العلوم ـ جامعة حلو ان **حدة الفارموجولى بمعهد القومى للورام

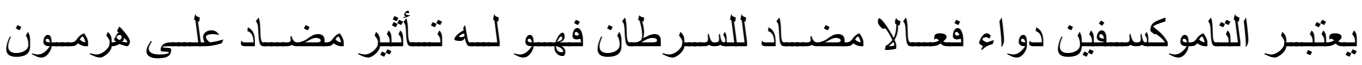

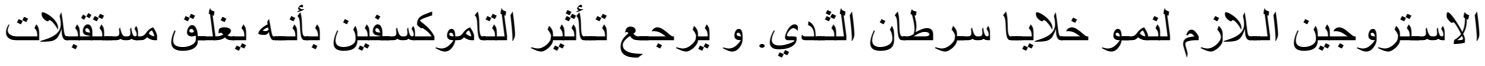

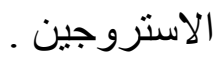

الغرض من هذه الدر اسة هو إثبات أن للتاموكسفين تأثير ا وقائيا ضد حدوث سرطان الثدي في فئر ان التجارب.

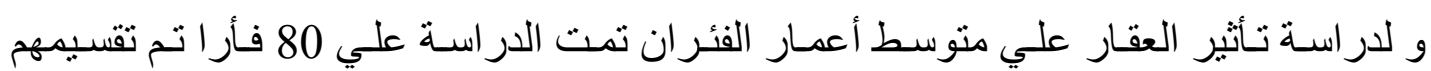
عشو ائيا كالتالي:

مجموعـة حقتـ بمحلـول ملحي لمدة 3 أسـابيع ثم حقنت بخلايـا الارلخ داخل التجويف البريتوني.

مجمو عة حقتت بعقار التاموكسفين لمدة 3 أسـابيع ثم حقتت بخلايـا الارلخ داخل التجويف البريتوني.

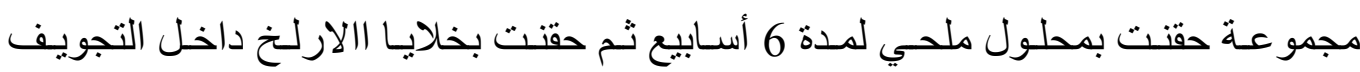
البريتوني.

هجمو عة حقتت بعقار التاموكسفين مدة 6 أسـابيع ثم حقتت بخلايـا الارلخ داخل التجويف البريتوني.

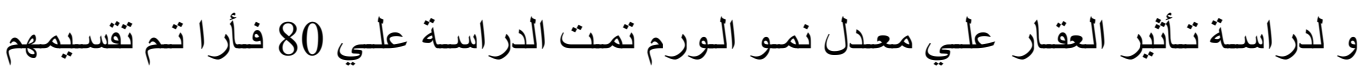

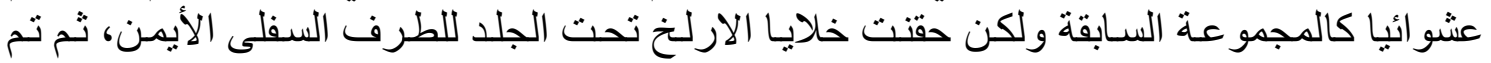

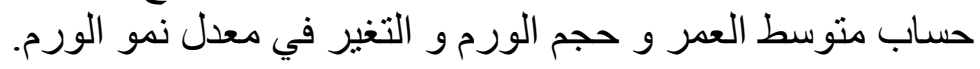
و لدر اسة الأثر السلبي للعقار على بعض الأعضاء, تمت الدراسة علي 40 فأر ا تم تقسيمهح عشو ائيا إلى مجمو عتين:

مجمو عه حقتت بالمحلول الملحي لمدة 6 أسابيع. • مجمو عه حقنت بالعقار لمدة 6 أسابيع

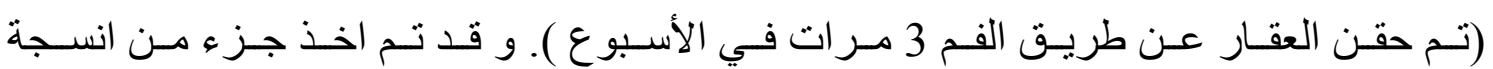

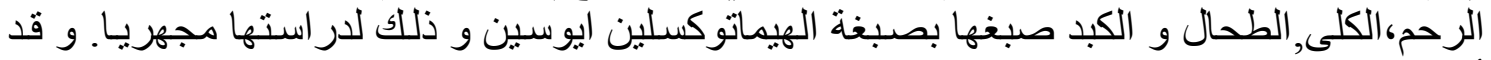
أوضحت الدر اسة ما يلي:-

ـ نقص ملحوظ في حجم الورم في المجمو عات المعالجة بالتاموكسفين لمدة 3 و 6 أسابيع و

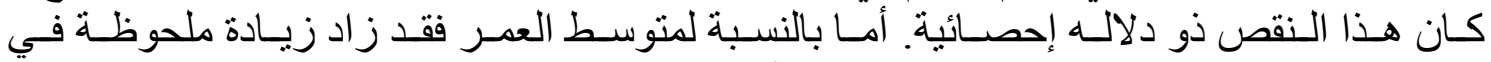

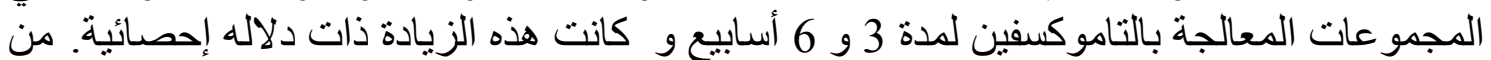

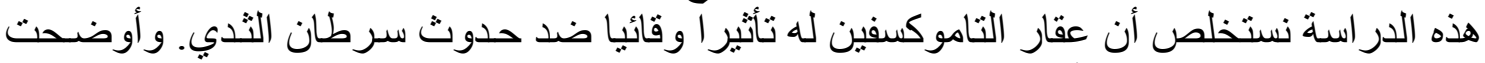

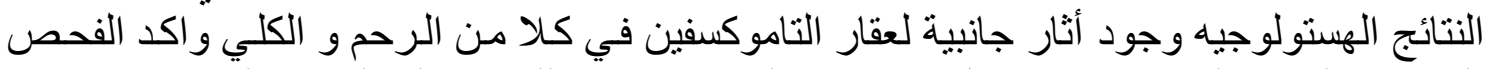

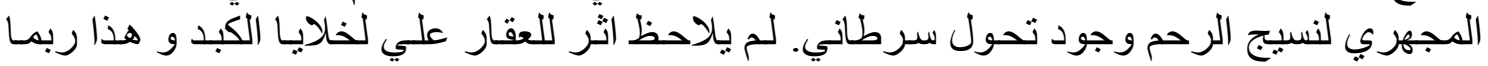


يرجع إليـ طريقة حقن الدواء عن طريق الفم، نوع الفئران المستخدمة، فترة المعالجة بالعقار ـ و اكد

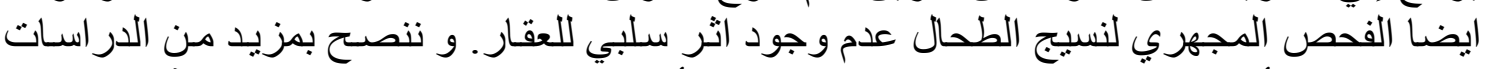

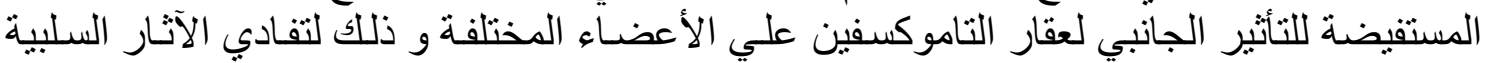
حتى نحصل علي اعلي استفادة من العقار. 